Prace Filologiczne. Literaturoznawstwo 10(13) 2020

ISSN 2084-6045

e-ISSN 2658-2503

Creative Commons: Uznanie autorstwa 3.0 PL (CC BY)

DOI: $10.32798 /$ pflit.578

\title{
WAR AND PEACE: THE THEME OF CONFLICT IN MODERN HEBREW LITERATURE OF THE LAST SEVENTY YEARS
}

\section{Wojna i pokój: motyw konfliktu we współczesnej literaturze hebrajskiej} ostatnich siedemdziesięciu lat

\author{
ELVIRA GRÖZINGER \\ Universität Potsdam, Niemcy \\ E-mail: e.dr.groezinger@gmail.com
}

\section{Streszczenie}

Współczesna literatura izraelska, począwszy od założenia państwa Izrael w 1948 roku, powstawała i powstaje w cieniu Zagłady. Jest również zdominowana przez tematykę konfliktu politycznego z arabskimi sąsiadami. W tym artykule zostaną zaprezentowane wybrane najważniejsze dzieła różnych gatunków prozy i poezji przedstawiające zawikłania tej skomplikowanej problematyki.

Słowa kluczowe: nowoczesna literatura izraelska, Shoah, konflikt polityczny, proza, poezja

\section{Abstract}

Modern Israeli Literature, starting with the foundation of the State of Israel in 1948 and overshadowed by the Shoah, until today is dominated by the theme of the political conflict with the Arab neighbours. In this article, some key works of different genres in prose and poetry depicting this state of affairs will be introduced.

Keywords: modern Israeli literature, Shoah, political conflict, prose, poetry

\footnotetext{
${ }^{*}$ The publication of this article was subsidised by the University of Warsaw.
} 


\section{Introduction}

The Hebrew Bible is full of stories about two antagonists combating, intriguing, scheming against each other. Some of these narratives have a deadly outcome and some a happy ending. The enmity is the result of the Fall and the expulsion of Adam and Eve from the Garden of Eden. The rivalry of Satan with and his plotting against God leads to a tragic hero's grudge against God for treating him unfairly, like in the case of the pious Job, etc. Above all, the Book of Genesis depicts frequent conflicts within Jewish families. Such is Abraham's split between him and his nephew Lot, who makes the wrong choice to go to Sodom, which almost costs him his life. One can also mention the antagonism of siblings, as for instance when Cain, the older brother, murders the younger, Abel, or the story of young Joseph being sold by his jealous older brothers to Egypt, or the enmity between the twins Jacob and Esau, etc. These oppositions are the mirrors of human nature in the sense carried by the proverb homo homini lupus... Finally, the Bible tells a lot about wars between tribes, nations, countries.

Already the Elizabethan tragedy Samson Agonistes by John Milton, a closet drama based on the history of Samson in the Biblical Book of Judges (13-16), picked up the topic of a Jew striving against an enemy. Modern Hebrew literature, written in the State of Israel since its founding in 1948, is to a large degree about the enmity of the Arabs towards their Jewish neighbours, and it oscillates between the two poles of war and peace, mirroring the reality of the country in which it emerged - the struggle of the Jews continues and so do its literary representations. The reasons for the enmity are cultural and religious: obedient Moslems don't accept "unbelievers" as equals among themselves except as Dhimma, i.e. tolerated tribute-paying members of Abrahamic religions like Christians and Jews. Due to this, the difficulty in establishing a peaceful coexistence has been and remains enormous.

Recalling the genesis of the foundation of the Jewish state, and the role that the Arab countries played in the process, might serve as an introduction to this article. On November 29, 1947, the General Assembly of the UN adopted a resolution regarding the partition of the British Mandate area for Palestine/ Eretz Israel. The resolution foresaw the creation of an independent Arab State along with an independent Jewish State, and the city of Jerusalem was placed under the International Trusteeship System. The Jewish side accepted the plan, while the Arabs did not, and instead they intensified their violent hostility towards the Jewish civilian population of approximately 600,000. Following the British withdrawal from the Mandate area on May 14, 1948, the Jewish People's Council under David Ben Gurion proclaimed the establishment of a Jewish State to be known as the State of Israel. Immediately after this proclamation, members of the Arab League such as the neighbouring Egypt, Transjordan, 
Syria, Lebanon, and Iraq attacked Israel, populated by newly arrived Holocaust survivors, immigrants from Nazi Europe, and old inhabitants of the former Ottoman Empire. Due to the British restrictions on Jewish immigration to Palestine, several thousands of illegally immigrated Jews had to defend their reborn homeland after 2000 years of exile, with untrained volunteer fighters armed with very few weapons. Victory in this bloody war after 6000 Jews were killed, $1 \%$ of the entire population, was a sheer miracle. The result of this first and the following wars of defence, which were initiated by Arab neighbours, was the flight and expulsion of 700,000 Arabs from the territory which is called in the Arab narrative "the Naqba". On the other side, 900,000 Jews from the Muslim countries were expelled in return.

Israel remains under permanent threat, and Arab-Jewish antagonism is continuously omnipresent in its literature and arts. ${ }^{1}$ The different aspects of conflict as a political trope, be they collective or individual, have been at the core of the modern Israeli literature since 1948. The unsolved Arab refugee problem, and the ensuing feeling of guilt among many Israeli writers, led to a controversial interpretation of the country's history, largely depending upon their political orientation. An inter-Israeli conflict emerged not only between Zionists and so-called post-Zionists and is visible within the Israeli society and in academia. The clash of narratives, not only between Jews and Arabs but also among the opposing political, ethnic, or religious groups within Israel, underlies the everyday life there today and, of course, provides a fertile soil for controversial and intellectual positions among the writers. Interestingly, there is no similar development within the Arab population, who regards itself primarily as history's permanent victims, while the Jews seek fault on their side. The truth lies somewhere in between, but Cicero's proverb "inter armae silent musae" does not pertain to Israeli literature.

\section{The Warrior-Hero and the Antagonist}

A double conflict is depicted in the prose of the controversial writer Yizhar Smilansky, pen name S. Yizhar (Rehovoth, 1916-2006, central Israel). He was a school teacher and later a professor of Hebrew literature and one of the most prominent and influential Israeli authors - even called "The Israeli James Joyce" because of the abundant inner monologues. He was the first writer to deal with the individual moral conflict of the Jewish fighters in the general conflict during the War of Independence (15 May 1948 - March 1949), in which he participated. The ad hoc drafted, largely inexperienced, very young men

${ }^{1}$ Cf. the successful Israeli TV series Fauda about undercover elite soldiers' mission in the West Bank. 
and women confronted Arab civilian individuals behind, between, and often at the front lines. Whereas the official historiography presents a clean and righteous war, Yizhar narrates dramatic episodes from behind the curtain and transmits a critical and subjective view of the events.

Yizhar was an ardent Zionist, but a critical one, as an intellectual should be. His monumental novel in two volumes on the War of Independence, The Days of Ziklag (published in 1958, ten years after the war), ${ }^{2}$ is considered a masterpiece of modern Hebrew literature and depicts both the strife for the homeland and anti-war humanism. The writer Abraham B. Yehoshua called it "the most instructive interior and sociological study of the spirit of the War of Independence generation". ${ }^{3}$ This double conflict is the dramatic theme of Yizhar's two short stories: "The Prisoner" ("Hashavui") ${ }^{4}$ and "The Ruins of Hizah" ("Hirbet Hiz'ah"), which he published soon after the war and which still generate a critical debate. In the first, Israeli soldiers capture an Arab shepherd who is innocently imprisoned after the soldiers steal his flock and beat him up. Some soldiers are depicted here as rough and sadistic perpetrators, the "soldatesca" type, who abandon Jewish ethics in which saving human life is an imperative (it is even allowed to trespass God's commandments in the time of danger or emergency). In the second story, which is about a captured Arab village, now deserted but a future home for Jewish immigrants, there is little ethics, too. This time no Arabs were killed, but the author nevertheless opposed the military action. Yizhar always claimed that his works on the war were purely fictional, and that by depicting this war he wanted to describe merely a universal, not specifically Israeli, dilemma.

Yizhar's internal conflict, psychomachia, is that between his loyalty to his comrades and the goal of victory on the one hand and the survival of the external conflict on the other. But he asks himself: "What the hell are we doing here?".

${ }^{2}$ Yizhar Smilansky, Yemey Ziklag (Tel Aviv: Zmora Bitan, 1958). Vide also: https://theun translated.wordpress.com/2017/05/21/the-great-untranslated-days-of-ziklag-by-s-yizhar/ (viewed 12.10.2018); Gideon Nevo, "The realism of S. Yizhar's Days of Ziklag”, Hebrew Studies, vol. 47 (2006): 299-320.

${ }^{3}$ Available at: http://www.ithl.org.il/page_14274 (viewed 13.01.2019). In Israel it is called the "Generation forty-eight".

${ }^{4}$ In Y. Smilansky, Midnight Convoy \& other Stories, with an introduction by Dan Miron, Middlebury College Library, 2007.

${ }^{5}$ Sipur Khirbet Khizeh (Merchaviya: Sifriyat Poalim, 1949); Siour Hirbet Hit'ah ve-od sheloshah sipurei milkhamah (Tel Aviv: Zmora Bitan, 1989). English translations: Jerusalem: Ibis, 2008; London: Granta, 2011; New York: Farrar, Straus and Giroux, 2014. The spelling of the Arabic name differs from publication to publication.

${ }^{6}$ Quoted after the German edition: Y. Smilansky, Geschichten vom Krieg und Frieden (Frankfurt am Main: Suhrkamp, 1997), 97. All translations are mine where no other source is named. 
He is the heroic fighter who has to defend himself and his innocent brethren after being attacked by the Arabs but is remorseful for causing the suffering of civilians, a situation inflicted upon him in which there is little place for scruples and hesitations. He criticises some individuals in his unit who act against the military order forbidding "violence and uncontrolled behaviour" - e.g. when these persons are cruel to camels - but his view of the Arab population is just as critical. He condemns their servility and corruptibility, e.g. when he describes how an Arab woman forces her little morbid daughter dressed in rags to dance in front of the soldiers and offers the child to them for sex. But here the woman errs - Jewish soldiers are diametrically opposed to her fellow Arabs because they never touch children, however coarse they may otherwise be.

Yizhar, Palestine-born, loved the battle according to his colleagues but hated the war, which he considered dirty. However, he insisted that the expulsions were aberrations, not the rule, but nevertheless claimed that a nation which suffered in the exile for so long, like the Jews, should not send other people into exile, not even the enemies. The military censors tried unsuccessfully to forbid "Hirbet Hiz'ah", and it is still controversially viewed. In his old age, Yizhar continued to warn against future wars.

\section{The Warrior-Antihero}

A fitting equivalent to Yizhar's war prose is the last novel by the Israeli writer Yoram Kaniuk, 1948, published in 2010, almost sixty years after the war and three years before he died. Kaniuk (1930-2013, born and died in Tel-Aviv) joined the war voluntarily at seventeen after dropping out of high school. He served in the then illegal Jewish commando forces Palmach under later Prime Minister Yitzhak Rabin. Kaniuk wrote down recollections that he claimed to be fictional and described the events of the distant past. But actually, the novel is both a historical narrative and a fiction. Kaniuk was originally trained in the underground marine Palyam, with the aim of smuggling in illegal immigrants, Holocaust survivors, as refugees from the camps for displaced persons in Europe. The heroic history of the ship Exodus made him join the illegal activity. The British Mandatory authorities impeded the immigration of Jews to Palestine under the pretext of insufficient economic resources and the lack of infrastructure for their integration by introducing restrictions and quotas. In truth, the British did not want to antagonise the Arabs who rejected the Jewish presence in the area. ${ }^{8}$ But as the small Jewish army needed support,

${ }^{7}$ Ibidem, 38 .

${ }^{8}$ This was due to one of the numerous White Papers, specifically the one from 1939 that was issued by the British Government under Neville Chamberlain under the pressure 
Kaniuk fought in the bloody battles on the ground, in the area of the then Arab-besieged Jerusalem, where the majority of Jewish fighters were untrained and lacked weapons. Kaniuk bemoans his young fallen comrades and calls this war a "Children's crusade". ${ }^{9}$ The Jewish fighters were neither politically informed about the state of affairs nor ideologically or technically firm in the battle. They were hungry, thirsty, disoriented, and died like flies. Kaniuk a controversial author like Yizhar ${ }^{10}$ - in retrospect views the war that eventually led to the creation of the Jewish state critically. He survived but reproached the commanders leading him and his young comrades into an ambush: "We had lost the best of our generation. There were so many dead in our brigade, and we were merely children, good and bad". ${ }^{11}$ His closest comrade and almost a friend was a young enigmatic Russian called Iska. He was twenty, with a merry character, supposedly a partisan who had fought the Germans at Stalingrad, and his philosophy was: "There is no ethics in a war [...] each animal kills another, every man fights for his life, and kills in order to survive. There is no such thing as a moral war". ${ }^{12}$ Iska was soon lethally wounded in Jerusalem, and Kaniuk mourned over him. On the other hand enemies usually remain anonymous to each other, they don't gain an epic dimension in the eyes of the narrating chroniclers and are not lamented over. Kaniuk, however, does feel pity for some of them, whom he considered innocent.

Kaniuk himself was heavily wounded by a Briton dressed up as an Arab. After the war, he lived for ten years in New York, but after his return he remained a critical "troublemaker". He remained rebellious, a fighter and an enfant terrible all his life, continuing to speak against religion and politicians. His conflict with the state authorities is mirrored in this novel, where he expressed his doubts about whether the history of his country - to which he nevertheless remained faithful - was not the fruit of the sacrifice of the young people fighting

of Haj Amin Eff el Husseini, a friend of Hitler and a radically anti-Jewish Mufti of Jerusalem. This document prevented the rescue of thousands of Jews from Nazi Europe between 1939 and 1945 and was valid until the British departure in May 1948. It limited Jewish immigration to 75.000 persons for five years and was accompanied by restrictions on the rights of Jews to buy Arab land. The Zionists continued to smuggle Jews into the country after the Second World War. This activity was made famous by Leon Uris' filmed Zionist epos, the novel Exodus (1960, with Paul Newman and Eva Marie Saint). The novel is about one of the ships, called "Exodus from Europe 1947", which was sent back to Europe and its 4515 passengers were interned again in the camps. This became an international affair, but soon after that the British opened the port of Haifa.

${ }^{9}$ Quoted after the German edition: Yoram Kaniuk, 1948 (Berlin: Aufbau Verlag, 2013), 103.

${ }^{10}$ Depending on the political stand of a reader or critic, he is either being applauded or slammed.

${ }^{11}$ Ibidem, 106.

${ }^{12}$ Ibidem, 105. 
for it. With all these doubts haunting him then and later in life, he is an antihero in his own eyes. Kaniuk, too, belongs to the surprisingly large group of internationally known and most prominent Israeli writers.

\section{God and the World against the Jews}

Modern Jewish writers, especially those of European origin, could not leave the Shoah (Holocaust) out of their oeuvre. Kaniuk was one of them. Although he was not a survivor himself, his most famous novel, Adam Resurrected (1968), relates to this subject. At the time of its publication, it was considered by the critics as one of the most powerful works of Holocaust fiction ever written. Adam Stein, the protagonist, former varieté artist, was spared the gas chamber by playing the role of a dog obeying the Nazi-commander of the concentration camp and spends the last years of his life in the 1960s in a mental asylum in the Negev desert. There he tries to help a young boy who fancies himself a dog, and through this overcomes his own trauma. The novel was adapted into a movie with Jeff Goldblum in the lead role in 2008.

The shadow of the Shoah has also dominated the lyrical works of the eminent Israeli poet Nathan Alterman. Born in Warsaw in 1910, he immigrated in 1925 to Israel and lived in Tel-Aviv until his death in 1970. When the news of the atrocities against Jews in Nazi-occupied Europe reached Palestine in 1942, Alterman wrote a sarcastic, bitter poem titled Of All the Peoples, in which he reproaches God for having chosen and forsaken his "chosen" people of Israel. Reproaching God for having disappointed his creation is a Biblical topic since Job, and a recurring theme of Jewish literature. Since the Biblical lamentations of Jeremiah, many Jewish poets found this genre appropriate for the sufferings of their people and did this during and after the Shoah as well. His poem was the most famous angry lamentation in Hebrew while the most famous one in Yiddish was by the poetess from Poland, Rajzel Żychlinska (1910-2001), who wrote her famous elegy "And God Hid His Face", leaving the Heavens "naked and empty". ${ }^{13}$

When under the gallows our children cried

We did not hear the world's wrath.

For of all the peoples you selected us

For us you loved and sanctified.

${ }^{13}$ Cf. Elvira Grözinger, “»Polen, Mein Vaterland!...« Das Bild der Heimat in der jiddischen Dichtung”, in Lesestuden/Lekcja czytania, eds. Ruth Leiserowitz, Stephan Lehnstaedt, Joanna Nalewajko-Kulikov, Grzegorz Krzywiec (Warszawa: Deutsches Historisches Institut Warschau, 2013), 107; Elvira Groezinger, Rajzel Zychlinski, "Poetical Trajectories in the Shadow of the Holocaust", in Women Writers of Yiddish Literature. Critical Essays, ed. by Rosemary Horowitz (Jefferson NC: McFarland, 2015), 284. 
For you selected us of all the peoples

Those of France, Japan and Norway.

And when our children march to the gallows

Smart Jewish kids, they all know

That their blood does not count and say

Mom, turn your eyes the other way.

The iron devoured day and night

And the holy Christian Father in the city of Rome

Did not come out with the icons of Christ

To stand one day in a pogrom.

To stand one day, one single day

Where for years like a lamb

A small

Unknown

Jewish kid

Stands alone.

Great is the worry about sculptures and paintings

Lest those art treasures are destroyed in a raid

But the heads of infants, art treasures they are,

Are smashed to the walls, and crushed on the roads.

Their eyes are begging: Mom don't look and don't see

Us lined lying in long rows on the ground.

We are famous old soldiers

Only short in size, aren't we?

They say with their eyes a few more words

"We know, God of our forefathers

That you selected us of all the kids in the world

That you loved and pampered us more than all others.

That of all the kids in the world us you selected

To be killed at the feet of your throne,

And our blood in small vases you collected

Because no one else would, only you alone.

And you smelled it like flowers

And you wiped it with your scarf

And for it you will charge both the killers

And the silence keepers." ${ }^{14}$

${ }^{14}$ Nathan Alterman, "Of All the Peoples", transl. Dan Ben-Amos, Moment, vol. 43, no. 3 (May/June 2018): 43. 
While Alterman wrote his poem in 1942, when the world was not aware of what was happening to the Jews in occupied Poland, the jeremiads and arguing with God can be found later in many post-Holocaust poems by Jewish writers. Alterman, although highly respected, was just as pugnacious as the two authors mentioned above. He was a sarcastic critic of war and atrocities. In his poem "Learning to kill", written during the Israeli independence war in 1948 and published in his weekly "The Seventh Column" in the daily newspaper Davar, he laconically stated: "Learning to kill / is a matter of momentum [...] learning to kill / Is a matter of habit" and accused the Israeli fighters of cruelty towards the enemy. ${ }^{15}$ Alterman, a poeta doctus and laureatus, was a rebel not just against God but a political one as well, opposing the government's policy.

\section{Physical Pain as an Antagonist}

The political conflict with the Arabs does not stop at the threshold of a private house or an apartment, like in the semi-biographical novel The Pain (Ke'ev, 2016) ${ }^{16}$ by the prominent female writer Zeruya Shalev, born in 1959, who is a victim of an Arab terror attack. On January 29, 2004, when she was returning to her home in the western part of Jerusalem, after taking her child to kindergarten, a Palestinian suicide bomber blew up a city bus just when she was passing by. It took her four months to recover from her injuries. The novel picks up the traumatic incident and transforms it into a net of physical and emotional feelings. The plot is as follows: ten years after she was seriously injured in a terrorist attack, the pain comes back to torment Iris, the heroine; Eitan, the love of her youth, also comes back into her life while Iris's marriage is in a crisis; her two children have grown up and are almost independent; she herself has become a successful school principal; although their relationship had ended many years before, she was wounded deeper when Eitan left her than by the suicide bomber who blew himself up next to her car; the affair must be kept secret while she tries to fathom whether her love can heal all her pain, and, more essentially, whether in the process she would have to inflict pain on the people who are closest to her.

Her description of the terror attack is striking and penetrating:

It was not even the intensity of the detonation, this almost volcano-like eruption of the explosive, not the nails, the screws, bolts, and nuts mixed with rat poison in order to cause heavier bleedings, which deafened her ears, but a different sound, deeper and worse than

${ }^{15}$ Yuval Ben Ami, "A song was born: The tale of a controversial tune", +972 Magazine, October 16, 2012. Available at: https:/www.972mag.com/a-song-was-born-the-tale-of-a-controversialtune/ (viewed 13.09.2019).

${ }^{16}$ For information about the book and the available translations and editions, vide http://www. ithl.org.il/page_15659 (viewed 15.10.2018). 
the explosion, the sound with which dozens of passengers parted from their lives, the laments of the mothers who leave orphans behind, the screams of young girls who will never grow up, cries of children who will never come home, of men who said goodbye to their wives, the moaning of the destroyed extremities, of the skin which was burnt, of the legs which would never walk again [...]. ${ }^{17}$

Thus, the political conflict, which is always present in the physical pain, now infiltrates her private life and causes a guilt-soaked moral conflict. Shalev's prose is sensual, erotic, and graphic even when depicting Arab terror, which is menacing and overshadows the everyday life of the inhabitants of her country. In her other novels, Shalev has been "writing intimate stories about emotions rather than ideologies, about the war between the sexes rather than a war between the nations" ${ }^{18}$ but here the latter intruded in the most brutal way into the intimate relationship. Zeruya Shalev is not a stranger to Polish readers. She visited Warsaw in September 2008, and several of her novels have been translated into Polish, including The Pain [Ból] ${ }^{19}$

\section{The Antagonistic Lovers}

Dorit Rabinyan's recent award-winning novel, All the Rivers (in Hebrew Gader Khaya, 2014, in Polish Żywoptot), ${ }^{20}$ is about an amour-fou between a young Israeli woman named Liat, who goes to New York City for a 6-month scholarship, and a young Palestinian Arab painter named Hilmi, who lives there. They have to hide their relationship from Liat's Zionist parents and Hilmi's orthodox Moslem mother. Only Liat's sister and Hilmi's siblings know about them being together.

Rabinyan, a daughter of Persian immigrants, belongs to the now-growing group of acclaimed Israeli writers with oriental roots. Born in 1972, she has introduced the culture of her ancestors to the communities of East and Middle European Jews. Retold by Rabinyan's heroine Liat, the modern variant of Romeo and Juliet's story, the emotional ups and downs of the momentary affair starting in November 2001 are also caused by the mutual distrust of the lovers. Astonishingly, 9/11 plays no role in this context, but the Arab-Israeli

\footnotetext{
${ }^{17}$ My translation after the German edition: Zeruya Shalev, Schmerz (Berlin: Verlag, 2016), 9f.

${ }^{18}$ Available at: https://jaipurliteraturefestival.org/burdens-of-identity-zeruya-shalev-salma-andnamita-gokhale-in-conversation-with-antara-dev-sen/ (viewed 15.10.2018).

${ }^{19}$ For example, Beata Zatońska, "Czas kryzysu to czas dojrzewania. Rozmowa z Zeruya Shalev", Lente-magazyn.com, available at: https://lente-magazyn.com/czas-kryzysu-to-czas-dojrzewaniarozmowa-z-zeruya-shalev/ (viewed 13.09.2019).

${ }^{20}$ Dorit Rabinyan, All the Rivers (New York: Penguin Random House, 2017). The book was first called Borderlife in English, and was later published in the USA under the new title. Vide also: Ian Fisher, https://www.nytimes.com/2017/05/03/books/its-complicated-the-path-of-an-israelipalestinian-love-story.html (viewed 03.02.2019).
} 
conflict does. "Cut this off quickly", Liat tells herself after their first night together. "Decide with a heavy but determined heart that it's better this way, better for both of us. And never see him again". ${ }^{21}$ This conflict is always present because the two have different, often contrary, perspectives: the Jews start to erect a wall of defence against Arab terror attacks, while the latter regard them as enemies and occupants. This is visible in the scene where Liat watches a video film sent by Hilmi's brother taken from a high apartment building, showing not only the Ramallah area and the surrounding Jewish settlements but also clearly Israel behind the border of the Green Line, as far as Tel Aviv, with the fine blue of the sea in the background. The short geographic distance between the two cities (Israel is very narrow in this area) shocked her when she saw how distinctly the hostile Arab neighbours could observe and film even the streets of Tel Aviv, presented to them like on a platter. This made her realise once more the permanently lurking warning in the back of her head, the dangerousness of this closeness, and the lack of privacy of Israeli people from men "from the other side". Guilt ridden, she worries about her vulnerable small country and its inhabitants, her relatives among them. But even this cannot affect their mutual love.

Hilmi, an intelligent and sensitive man, dreams of the sea he missed in the stony desert area of Ramallah, while Liat, having grown up in Tel Aviv with the seaside, is surprised that he cannot swim. They plan to meet someday on the shore in Israel. After her return, he travels to Ramallah to visit his family and be closer to her. They try to stay in contact via cell phone, but the contact does not always work, and ultimately this proves to be fatal. The end of the novel is startling, there is no happy ending, but rather an unexpected one. One day, Hilmi comes illegally by car with his relatives for one day only to Tel Aviv with the aim of meeting Liat. But he cannot reach her by phone. When her phone finally rings, it is not Hilmi but his brother who informs her of Hilmi's death. However, he did not die as she first thought in her panic and shock, being a victim of the political conflict and shot by Israeli soldiers; no, he drowned in the sea near the shore in Jaffa, in an area where swimming is forbidden. He had Liat's near-by coast of Tel Aviv just before his eyes.

This fictional novel, dedicated to an obviously Arab man called Hasan Hourani (1973-2003), has led to an internal political conflict between the right- and the left-wing in Israel when the right-wing Israeli Education Ministry announced it has taken Rabinyan's book off its approved list for high schools, as it depicts the Arab enemies positively. However, teachers can still use it unofficially

${ }^{21}$ Quoted after the German edition: Wir sehen uns am Meer (Köln: Kiepenheuer \& Witsch, 2016), 82. 
if they wish to. The author defended the figure of Hilmi as an individual and a literary creation against the ban which made international headlines, many of them criticising the government's decision.

\section{The Conflict of Identities}

Whereas Rabinyan merely hints at the idiosyncrasy of co-existence in this difficult constellation, one of the few Israeli Arabs who write in Hebrew, Sayed Kashua, has made it into his main topic. Born in 1975 in the town of Tira, in Israel's so-called "Triangle" Arab area existing since 1948, he was then the only Moslem accepted to a renowned boarding school for gifted children in Jerusalem. Later, he studied sociology and philosophy at the Hebrew University in Jerusalem. He gained fame as a provocative weekly columnist for the leftist paper Ha'aretz and the Jerusalem local weekly Ha'ir, as a novelist, and as an author of the popular Israeli satirical TV sitcom Avoda Aravit (2007, Arab Labour), which includes autobiographical elements like all the rest of his works. The TV show tells the history of a young Arab couple with a little daughter, desperately but unsuccessfully trying to assimilate into the Jewish society, making the clash of civilizations and prejudices on both sides evident. Kashua is ironic and self-ironic, critical of both Jewish and Arab Israelis, but reproaches the first for the lack of tolerance towards the Arabs in their midst. As the Arab countries have no Jewish inhabitants, while their Christian population is being persecuted, the two nations coexist only in the Israeli democracy. The leftist critics and international media thus find fault on the Israeli side only, whereas the Jewish audience adores him, and the Arabs criticize him for having presented them in a negative way and "unfairly". Kashua's prose is, indeed, subversive and he uses humour, exaggeration, and irony as literary devices with the function of a shield. As a satirist, he hopes to amend the society by holding a mirror up to it.

His first novel, Dancing Arabs (2002), ${ }^{22}$ describes the difficulties of an Arab adjusting to Western culture, for instance when the family of his main protagonist, the boy Eyad, takes the meals on the floor, and he has to learn to eat at a table. The alter ego, born in Tira like the author, grows up in a problematic family, as his grandfather was killed in the 1948 war, and his father was jailed for two years before he was married, after he had been accused of blowing up a university cafeteria. The son refuses to become a hero, against his father's wish, who would like him to become a terrorist too. In the early 1980s, his classmate Naomi and Eyad fall in love with each other, but their relationship fails as well

${ }^{22}$ The book was originally published in Hebrew (Aravim Rokdim) by Keter publishers, Ben Moshav Shemen in 2002, and was translated into English in 2004. Vide also: Danna Harman, https://www.haaretz.com/life/television/.premium-a-dancing-arab-caught-between-two-worlds1.5254740 (viewed 12.12.2018). 
due to family and social pressure. His attempt to leave his Arab roots and identity behind was in vain, and at the end Eyad says: "I'm a failure anyway". ${ }^{23}$ $\mathrm{He}$ considers being an "Israeli Arab" as a "humiliation". ${ }^{24}$

Kashua left Israel with his family after accepting a teaching position in the USA in 2014, and he is now a professor of practice in the Israel Studies program at the University of Illinois at Champaign-Urbana. After his departure abroad, a volume collecting his humorous, widely read weekly columns was published in Israel. In Native: Dispatches from an Israeli-Palestinian Life, ${ }^{25}$ he plays the role of a model representative of a minority. Here, like in his other works, the main theme is the problem of identity of an Arab in the Israeli society. The mixture of lachrymoseness with self-pity and pride about being a VIP in the Jewish country are his literary trademark. In this book, Kashua documents his family life in Israel and draws a self-ironic caricature, which reminds the reader very strongly of Ephraim Kishon, the Hungarian-Jewish Holocaust survivor and a master of satirical glosses in the Israeli daily newspaper Ma'ariv in the years 1952-1982. In one of the amusing stories, "Holy work" (published in the mentioned collection), Kashua describes his experience with a cleaning woman. After a desperate search, he finally finds one with the help of a Jewish friend who warns him that this orthodox Jewish-Iraqi woman must never discover for whom she is working because she would never serve an Arab family. Before she arrives in the morning, when his wife and kids are not at home, the author, now called Israel, hides all the things which might betray the secret - family photos, Arab kitsch items, books, etc., - in the wardrobe. He leaves the house and returns on time to pay her for the work, which she accomplished perfectly. The apartment is spotless, but the woman behaves strangely, and he is scared she might have also cleaned in the wardrobe and found the things hidden there. She addresses him in a hilarious scene:

Listen, Israel, just in case this is your name, and you don't need to worry, sweetie, believe me, it is holy work you're doing. My mouth stayed opened as I did not tell her what I am doing. And she ended with: "It is a great honour for me to work for such a man". She took the money and whispered with a twinkle in her eye: "My father was also in the Secret Service". ${ }^{26}$

${ }^{23}$ Quoted after: Deborah Harris, "Dancing Arabs”, Publishers Weekly, available at: https://www. publishersweekly.com/978-0-8021-4126-2 (viewed 12.12.2018).

${ }^{24}$ Cf. Faria Rowshan, Analysing the Arab-Israeli Identity Crisis in the Author Sayed Kashua's "Dancing Arabs" and "Let It Be Morning", unpublished MA thesis, Brac University, 2018. Available at: http://dspace.bracu.ac.bd/xmlui/bitstream/handle/10361/10779/16363006_ENH.pdf? sequence $=1 \&$ isAllowed $=$ y (viewed 12.12.2018).

${ }^{25}$ Hebrew 2015, English edition 2017.

${ }^{26}$ Quoted after the German edition: Sayed Kashua, Eingeboren. Mein israelisch-palästinensisches Leben. Kolumnen aus den Jahren 2006-2014 (Berlin: Verlag, 2016), 229. 
The journalist Debra Kamin wrote about Kashua: "the greatest living Hebrew writer is Arab". ${ }^{27}$ She refers especially to Kashua's sitcom Arab Labour and the conflict of identities depicted there - Arabs versus Jews. The humiliating and oft futile effort to be accepted by the majority and the clash of civilizations are presented by the satirist in a seemingly trivial manner, but in reality it makes up the very basis of the deadly antagonisms in the everyday life which are pervading the modern Israeli literature since its very beginning.

\section{Conclusion}

As we can sum up, the spirit of Agon prevails in the modern and contemporary Hebrew literature, of which some samples are presented here, which is a mirror of the troubled religious and ethnic melting pot. Also due to the political situation, in most of the works - both prose and poetry - the tensions depicted are recurring too, building a bridge to the old battles of biblical times, and there are no signs of a positive change in the near future.

\section{Bibliography}

Alterman, Nathan. Of All the Peoples, transl. Dan Ben-Amos. Moment, vol. 43, no. 3 (May/June 2018): 43.

Grözinger, Elvira. "»Polen, Mein Vaterland!...« Das Bild der Heimat in der jiddischen Dichtung”. In Lesestuden/Lekcja czytania, eds. Ruth Leiserowitz, Stephan Lehnstaedt, Joanna Nalewajko-Kulikov, Grzegorz Krzywiec. Warszawa: Deutsches Historisches Institut Warschau, 2013.

Groezinger, Elvira, Rajzel Zychlinski. "Poetical Trajectories in the Shadow of the Holocaust". In Women Writers of Yiddish Literature. Critical Essays, ed. by Rosemary Horowitz. Jefferson NC: McFarland, 2015.

Kaniuk, Yoram. Adam Ressurected. New York: Grove Press, 2000 [1968].

Kaniuk, Yoram. 1948. Berlin: Aufbau Verlag, 2013.

Kashua, Sayed. Aravim Rokdim. Ben Moshav Shemen: Keter Publishers, 2002.

Kashua, Sayed. Eingeboren. Mein israelisch-palästinensisches Leben. Kolumnen aus den Jahren 2006-2014. Berlin: Verlag, 2016.

Kashua, Sayed. Native: Dispatches from an Israeli-Palestinian Life. New York: Grove Press, 2017.

Nevo, Gideon. "The realism of S. Yizhar's Days of Ziklag”. Hebrew Studies, vol. 47 (2006): 299-320.

Preminger, Otto (dir.). Exodus, prod. Carlyle-Alpina, distr. United Artists. 1960.

Rabinyan, Dorit. Wir sehen uns am Meer. Köln: Kiepenheuer \& Witsch, 2016.

${ }^{27}$ Debra Kamin, "The Greatest Living Hebrew Writer Is Arab", The Tower, June 2013, available at: http://www.thetower.org/article/the-greatest-living-hebrew-writer-is-an-arab/. 
Rabinyan, Dorit. All the Rivers. New York: Penguin Random House, 2017.

Rowshan, Faria. Analysing the Arab-Israeli Identity Crisis in the Author Sayed Kashua's "Dancing Arabs" and "Let It Be Morning", unpublished MA thesis. Brac University, 2018.

Shalev, Zeruya. Schmerz. Berlin: Verlag, 2016.

Shalev, Zeruya. The Pain. New York: Penguin Random House, 2019.

Smilansky, Yizhar. "The Ruins of Hizah”. 1949.

Smilansky, Yizhar. Yemey Ziklag. Tel Aviv: Zmora Bitan, 1958.

Smilansky, Yishar. Geschichten vom Krieg und Frieden. Frankfurt am Main: Suhrkamp, 1997.

Smilansky, Yizhar. "The Prisoner”. In Midnight Convoy \& other Stories, with an introduction by Dan Miron. Middlebury: Middlebury College Library, 2007.

Uris, Leon. Exodus. New York: Doubleday \& Company, 1958.

Zychlinsky, Rajzel. God Hid His Face: Selected Poems, transl. Barnett Zumoff, Aaron Kramer, Marek Kanter. Santa Rosa CA: Word \& Quill Press, 1997.

\section{Internet sources}

Ben Ami, Yuval, "A song was born: The tale of a controversial tune", +972 Magazine, October 16, 2012, https://www.972mag.com/a-song-was-born-the-tale-of-a-controversialtune/ (viewed 13.09.2019).

Fisher, Ian, https://www.nytimes.com/2017/05/03/books/its-complicated-the-path-of-anisraeli-palestinian-love-story.html (viewed 03.02.2019).

Harman, Danna, https:/www.haaretz.com/life/television/.premium-a-dancing-arab-caughtbetween-two-worlds-1.5254740 (viewed 12.12.2018).

Harris, Deborah, "Dancing Arabs", Publishers Weekly, available at: https://www.publishers weekly.com/978-0-8021-4126-2 (viewed 12.12.2018).

Kamin, Debra, "The Greatest Living Hebrew Writer Is Arab", The Tower, June 2013, available at: http://www.thetower.org/article/the-greatest-living-hebrew-writer-is-an$\mathrm{arab} /$ (viewed 28.01.2020).

Yehoshua, Abraham B., http://www.ithl.org.il/page_14274 (viewed 13.01.2019).

Zatońska, Beata, "Czas kryzysu to czas dojrzewania. Rozmowa z Zeruya Shalev”, Lentemagazyn.com, available at: https://lente-magazyn.com/czas-kryzysu-to-czas-dojrzewaniarozmowa-z-zeruya-shalev/ (viewed 13.09.2019).

\section{Anonymous Internet sources}

http://www.ithl.org.il/page_15659 (viewed 15.10.2018).

https://www.jaipurliteraturefestival.org/burdens-of-identity-zeruya-shalev-salma-and-namitagokhale-in-conversation-with-antara-dev-sen/ (viewed 15.10.2018).

https://www.theuntranslated.wordpress.com/2017/05/21/the-great-untranslated-days-ofziklag-by-s-yizhar/ (viewed 12.10.2018). 
ELVIRA GRözINGER, born in 1947 in Poland as a child of Holocaust survivors, she grew up in Israel. She received a B.A. from the Hebrew University of Jerusalem (English and French Literatures, Jewish History, History of Arts). Living since 1967 in Germany, she obtained Translators' Diploma from the University of Heidelberg, then studied German Literature and Jewish Studies in Frankfurt on the Main. She obtained a doctorate in General and Comparative Literature from the Freie Universität Berlin. She worked as lecturer and scientific researcher at universities and academic institutes in Frankfurt, Darmstadt, Potsdam, and Berlin, now retired. Author of 9 books, mainly on Jewish culture and literature in different languages, 220 scholarly articles and book reviews, plus 100 short articles. Latest publications: "Zwischen den Welten. Die polnischjüdischen Autoren in den Übertragungen von Karl Dedecius" (in Oder Übersetzen, 2018/19), "Le retour des suffragettes?/Die Rückkehr der Suffragetten? Ein Kurzer Essay zur aktuellen Debatte über Frauenrechte und Feminismus" (in Dogma, Revue de Philosphie et de Sciences Humaines, 2019). 